PERM JOURNAL OF PETROLEUM AND MINING ENGINEERING

ВЕСТНИК ПНИПУ. ГЕОЛОГИЯ. НЕФТЕГАЗОВОЕ И ГОРНОЕ ДЕЛЮ

ISSN 2224-9923

Volume / Tом 20 №2, 2020

http://vestnik.pstu.ru/geo/

UDC 622.276.04(261.24)

Article / Статья

(c) PNRPU / ПНИПУ, 2020

\title{
NUMERICAL SOLUTION OF GEOMECHANICAL PROBLEMS (THE CASE OF THE BALTIC SEA SHELF FIELD)
}

\author{
Nadezhda A. Liadova, Pavel I. Klykov, Andrei A. Predein
}

PermNIPIneft branch of LUKOIL-Engineering LLC in Perm (3a Permskaya st., Perm, 614015, Russian Federation)

\section{ЧИСЛЕННОЕ РЕШЕНИЕ ЗАДАЧ ГЕОМЕХАНИКИ (НА ПРИМЕРЕ МЕСТОРОЖДЕНИЯ ШЕЛЬФА БАЛТИЙСКОГО МОРЯ)}

\section{Н.А. Лядова, П.И. Клыков, А.А. Предеин}

Филиал ООО «ЛУКОЙЛ-Инжиниринг» «ПермНИПИнефть» в г. Перми (614015, Россия, г. Пермь, ул. Пермская, 3a)

Received / Получена: 17.02.2020. Accepted / Принята: 15.04.2020. Published / Опубликована: 15.06.2020

Key words:

geomechanics, stress state computation, finite element method, wellbore stability, pore pressure, rock caving pressure, drilling mud absorption pressure, hydraulic fracturing pressure, horizontal drilling, Baltic Sea shelf.

\begin{abstract}
Geomechanical modeling aims at solving problems associated with ensuring accident-free well drilling. The paper deals with building a numerical 3D geomechanical model for a studied field with a further production well stability computation. The region of operations is located in the Baltic Sea shelf. Apart from the field summary, the study contains results of acquisition and audit of initial data for modeling. The method is discussed for unidimensional geomechanical modeling on key wells, including determination of dynamic and static elasticity and strength of the rock varieties, computations of pore pressure, vertical and horizontal stresses. Well stability computations have been obtained and analyzed on the basis of the findings of 1D geomechanical modeling. A further analysis deals with the results of 3D geomechanical modeling, i.e. determination of boundaries and building a structural framework of the model, geometry testing, filling the grid with mechanical properties, and computation of complete stress tensor using the finite element method (FEM). Results of the 1D- and 3D-modeling have been compared. Thus, a numerical 3D geomechanical model has been built for the field under study. The following stage of works was focused on the wellbore stability computation for the planned wells. Additionally, computation was performed for drilling mud absorption pressure gradient cubes, caving pressure, and rock hydraulic fracturing pressure at different inclination angles and drilling azimuths. Recommendations were developed for accident-free construction of wells in the field under study, including upkeep and update of the geomechanical model in real time during drilling of wells. The obtained results and techniques can be used in design and construction of wells in other fields though taking into account regional specifics.
\end{abstract} Рассматриваются результаты геомеханического моделирования для решения задач в области обеспечения безаварийной последуюшим расчетом устойчивости эксплуатационных скважин. Район работ расположен на шельфе Балтийского моря. Помимо краткой характеристики месторождения приведены результаты сбора и аудита исходных данных для моделирования. Рассмотрена методика одномерного геомеханического моделирования на опорных скважинах, в том числе определение динамических и статических упругопрочностных характеристик пород, расчет порового давления, вертикального и горизонтального напряжений. Получены и проанализированы расчеты устойчивости скважин по результатам 1D-геомеханического моделирования. Далее анализируются результаты трехмерного геомеханического моделирования: определение границ и построение структурного каркаса модели, тестирование геометрии, наполнение сетки механическими свойствами, а также расчет полного тензора напряжений методом конечных элементов (МКЭ). Проведено сопоставление результатов 1D- и 3D-моделирования. Таким образом, построена численная 3D-геомеханическая модель для исследуемого месторождения. Следующим этапом работ был расчет устойчивости стволов скважин для планируемых скважин. Дополнительно рассчитаны кубы градиентов давления поглощения бурового раствора, давления обрушения и гидроразрыва пород при различных зенитных углах и азимутах бурения. Разработаны рекомендации для безаварийного строительства скважин на исследуемом месторождении, в том числе по сопровождению и обновлению геомеханической модели в режиме реального времени в процессе бурения скважин. Полученные результаты и методика выполнения работ могут быть использованы при проектировании и строительстве скважин на других месторождениях с учетом региональных особенностей.

Nadezhda A. Liadova (Scopus ID 36712086700) - PhD in Geological and Mineralogical Sciences, Associate Professor, Deputy General Director - Director (tel.: +007342 23367 81, e-mail: nadezhda.lyadova@pnn.lukoil.com).

Pavel I. Klykov (Scopus ID 57142417500) - Chief Specialist of the Conceptual well Modeling Department (tel: +007 342 233 67 81, e-mail: Pavel.Klykov@pnn.lukoil.com). The contact person for correspondence.

Andrei A. Predein (Scopus ID 35791342300) - Head of the Conceptual Well Modeling Department (tel: +007 342 233 62 65, e-mail: Andrej.Predein@pnn.lukoil.com).

Лядова Надежда Алексеевна - кандидат геолого-минералогических наук, доцент, заместитель генерального директора - директор (тел.: +007 3422336781 , e-mail: nadezhda.lyadova@pnn.lukoil.com).

Клыков Павел Игоревич - главный специалист отдела концептуального моделирования скважин (тел.: +007 342 233 67 81, e-mail: Pavel.Klykov@pnn.lukoil.com). Контактное лицо для переписки.

Предеин Андрей Александрович - начальник отдела концептуального моделирования скважин (тел.: +007 34223362 65, e-mail: Andrej.Predein@pnn.lukoil.com). 


\section{Introduction}

Compared to onshore drilling, offshore drilling is characterized with high capital costs of well constructions. Besides, the learnings from drilling operations in the Baltic Sea shelf suggest such complications as wellbore wall caving-in or collapse, drilling mud absorption etc. Time and materials spent for rectification of complications make costs even higher. Globally, one of the indispensable conditions for successful and accident-free constructions of horizontal wells in difficult geological conditions lies in the presence of a 3D geomechanical model as a basis for design solutions in production drilling [1-14]. The paper proposes a method and results obtained from building a 3D geomechanical model of one of the Baltic Sea offshore fields. The study is based on the oil-andgas geomechanics principles [15-19].

\section{Input Data}

The region of operations is situated in the Baltic Sea shelf. In terms of tectonic regions, it is a structurally complex anticlinal uplift in the central part of the West Curonian swell of the Curonian deep. It is a dome-like fold of the sub-meridional extension, complicated from the East by a rupture fault with amplitude of $20-50 \mathrm{~m}$. The productive part of the section is represented by terrigenous deposits of the Cambrian system $(\mathcal{C})$. Three prospecting wells have been drilled in the field. The input data for building the $3 \mathrm{D}$ geomechanical model is as follows:

- Geoinformation system (GIS) data: GIS intermediate records, summary plotter and interpretation results

- Well drilling data: drilling reports, daily reports, final reports, sampling and testing data

- Seismic material: reports, structural horizon maps in depth and time domain, seismic cube of amplitudes, velocities, and inversion results

- Project well profiles, project spot coordinates

- Field geological model: faults, structure surfaces, cubes of properties (porosity, permeability etc.).

It is notable that the model is made within the boundaries of the productive part. The overlying rock/intervals were not modeled. In scope of the geomechanical modeling, these intervals will be added using special software.

The aforementioned parameters were subjected to a qualitative and quantitative analysis. In the intervals with absent GIS data, synthetic curves have been computed. The initial data was prepared for building a geomechanical model.

Extensive core sampling has been performed in key wells drilled in the productive part of the section.
No sampling of overburden intervals has been made. The program suggested acoustic tests of rock samples in atmospheric and reservoir conditions. Rock elasticity and strength destructive tests have not been performed. The absence of a complete core analysis creates certainty in computation of the static elasticity and strength.

\section{Building a 1D Geomechanical Model}

The model of rock elasticity and strength propagation across the section is the main input information for computation of wellbore walls stability. The model of mechanical properties constitutes a numerical representation of rock and reservoir pressures, tectonic stresses, mechanical and strength properties of rock, including their strain parameters. The computation is based on the geophysical research data, core analysis results of mechanical properties, taking into account the geological information. Calibration is based on tests and measurements in the wells and drilling events data.

\section{Dynamic elasticity and strength properties of rocks}

Dynamic elasticity and strength properties of rocks include Young's modulus, bulk compression modulus, shear modulus, and Poisson's ratio, which describe how the rock reacts to short-term loads, such as transit of acoustic waves. The main data for computation of dynamic characteristics are longitudinal and transverse wave velocities, and rock density. These parameters are associated with elastic properties in the following manner.

Young's dynamic modulus is calculated as follows:

$$
E_{\text {dynamic }}=\frac{\rho V_{s}^{2}\left(3 V_{p}^{2}-4 V_{s}^{2}\right)}{\left(V_{p}^{2}-V_{s}^{2}\right)},
$$

where $V_{p}, V_{s}$ are velocities of the longitudinal and transverse waves, respectively, $\mathrm{m} / \mathrm{s}$.

Poisson's dynamic ratio:

$$
v_{\text {dynamic }}=\frac{V_{p}^{2}-2 V_{s}^{2}}{2\left(V_{p}^{2}-V_{s}^{2}\right)},
$$

where $V_{p}, V_{s}$ are velocities of the longitudinal and transverse waves, respectively, $\mathrm{m} / \mathrm{s}$.

The advantage of determining the elastic moduli based on the well logging data is the continuity of the obtained profile of these parameters in terms of depth, and high resolution (for key wells, an increment of $0.2-0.4 \mathrm{~m}$ is available). 
An acoustic logging record has been obtained for the key wells. Acoustic logging curves have been calibrated using actual velocity/slowness measurements obtained on the core material in reservoir conditions. The missing transverse wave logging data were recovered on the basis of multivariate regressions.

\section{Static elasticity and strength properties of rocks}

Static elasticity and strength properties of rocks determine the their response to high-amplitude, prolonged and irreversible strains occurring, inter alia, when wellbore walls lose stability (unloading due to drilling-out of rock). For most rock varieties, static elasticity and strength properties are much different from the dynamic ones.

Static elasticity and strength properties include static Young's modulus (Est), static Poisson's ratio (PRst), ultimate compression strength (UCS), ultimate tensile strength $(T S)$, internal friction angle $(F A)$ and cohesion (CS).

Transition from dynamic to static elasticity and strength properties requires use of correlations (constraint equations) obtained during interpretation of the core analysis results. We used correlation dependencies obtained in the adjacent similar fields calibrated with actual measurements.

\section{Stress computation}

Vertical stress of the environment is determined by the weight of overburden rock and water column. The weight is calculated from the product of rock/water density by acceleration of gravity:

$$
O B G(z)=g \int_{0}^{z} \rho d z,
$$

where $O B G(z)$ is vertical stress, $\mathrm{Pa} ; \rho$ is specific desity, $\mathrm{kg} / \mathrm{m}^{3} ; g$ is acceleration of gravity, $\mathrm{m} / \mathrm{s}^{2} ; z$ is a vertical depth, $\mathrm{m}$.

For calculation of maximum and minimum horizontal stresses, classical formulas of the poroelastic model are used [15]:

$$
\begin{aligned}
& \sigma_{h}=\frac{v}{1-v}\left(\sigma_{v}-\alpha \sigma_{p}\right)+\alpha \sigma_{p}+\frac{E s t}{1-v^{2}} \varepsilon_{h}+\frac{v E s t}{1-v^{2}} \varepsilon_{H}, \\
& \sigma_{H}=\frac{v}{1-v}\left(\sigma_{v}-\alpha \sigma_{p}\right)+\alpha \sigma_{p}+\frac{E s t}{1-v^{2}} \varepsilon_{H}+\frac{v E s t}{1-v^{2}} \varepsilon_{h},
\end{aligned}
$$

where Est is Young's static modulus, $\mathrm{Pa}$; $v$ is Poisson's static ratio, un.; $\varepsilon_{H}, \varepsilon_{h}$ are strains in the directions of maximum and minimum horizontal stresses, respectively, un.; $\sigma_{v}$ is vertical stress (rock overburden weight), $\mathrm{Pa} ; \sigma_{p}$ is a minimum effective horizontal stress, $\mathrm{Pa} ; \alpha$ is Biot's constant.

Computation of the minimum horizontal stress in the wells is performed using the acoustic logging data and computed profiles of static elasticity and strength properties, reservoir pressure and vertical stress.

Calibration of the computed minimum horizontal stress profiles was performed using the results of the conducted LOT and ELOT (rock hydraulic fracturing tests).

\section{Wellbore wall stability modeling}

Caving-in of the wellbore walls can be caused by shear or rupture failures of rock due to the imbalance of stresses concentrating around the well.

Stability computation involves computation of stress concentration on the wellbore wall (radial, tangential/circumferential and axial) and checking fulfilment of the rock breaking condition (using MohrCoulomb criterion) [20-22].

For an inclined well, stress distribution on the wall will depend not only on the magnitude of the main stresses, but also on the trajectory of the well relative to the direction of the main stresses.

Results of the wellbore stability computation represent a summary plot of the gradients of reservoir pressure, caving, drilling mud absorption and reservoir hydraulic fracturing.

\section{Building a 3D Geomechanical Model}

Boundaries of the geomechanical model are limited by the test range which includes rupture failures, exploration wells and planned locations of production wells. An algorithm has been developed for building a 3D geomechanical model. Fig. 1 shows a flow chart of processes performed in the course of building the field model.

In the beginning of the model building, three processes occurred simultaneously: 1) analysis of the well logging data and their preparation to integration into the structural framework for a further propagation into the interwell space (a choice of a level-by-level representation of the section); 2) preparation of seismic data for use after propagation of the well data in the interwell space; 3) a correction of the available structural surfaces, creation of additional surfaces and formation of surfaces from the transferred fracture lines for to create a correct structural framework.

This is followed by the results binding of the three parallel processes into one process; the structural framework is formed and completely filled with the data necessary for computation of mechanical properties - density, velocity of acoustic longitudinal 


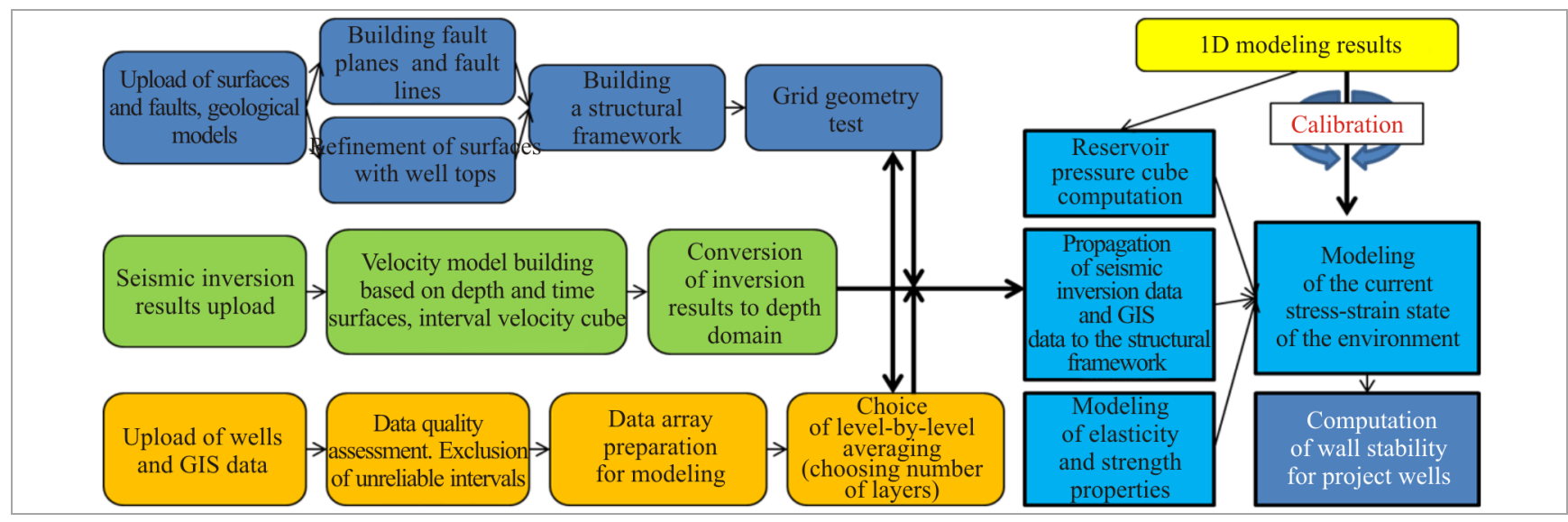

Fig. 1. Flow chart of 3D geomechanical model building process

and transverse waves. Computation of cubes of elasticity and strength properties is performed within the structural framework; quality assessment is performed with the data obtained in the 1D geomechanical modeling.

The finite element method with setting of boundary conditions is used for computation of a complete stress tensor, and strains in each cell of the 3D geomechanical model. Repeatability of the modeling results against the $1 \mathrm{D}$ geomechanical computation data is checked by key wells. In the next stage, the numerical modeling results were used for computation of the production wellbore stability. The modeling method is based on loading the model with vertical stress (computed on the basis of the weight of each overlying cell) and regional horizontal stresses. Each cell of the model under load contains mechanical properties (Young's modulus, Poisson's ratio, compression and tensile strength, internal friction angle), and has its own density value. The model cells are rigidly bound together, so that the strain of each cell is computed not only on the basis of the cell's own elasticity and strength, but also on the properties of the surrounding cells. Thus, the model is not a collection of individual independent elements but an integral system.

Building a 3D model of stress state involves four main stages.

\section{Building a structural framework (grid)}

Building a structural model is almost completely identical to building a similar model for calculation of reserves or hydrodynamic modeling. The only distinguishing feature of the structural model for geomechanical modeling is its prerequisite of a high quality. This means that the grid for geomechanical modeling cannot contain inverted cells (cells with negative volume), and all cells must be convex.
The structural framework building involved binding of structural surfaces with the well top data, followed up by control using GIS data.

Upon completion of structural maps building, the quality of faults has been assessed. From the geological model, the fault is located in the region of the 3D geomechanical model building; however, it was only traced in the productive horizon interval. Based on the seismic information, this fault was built upward until its attenuation. Implementation of the fault into the model is performed at the properties setting stage. Cells crossing the fault are traced, and then the properties of the fault are assigned to the cells. In fact, this way the failure area around the fault is also modeled and taken into account for the computation.

Thus, a structural framework is formed with the horizontal cell size of $100 \times 100 \mathrm{~m}$, the number of layers 2203. The number of cells is around 9 million.

\section{Framework geometry testing}

The structural grid quality is very important for geomechanical modeling, since any problems with the cell geometry in numerical modeling cause emergence of unnatural stress concentration zones. In order to perform this test, the ground surface and/or sea level of the model have been set as an even plane, whereas all cells have been assigned the same mechanical properties and strains. It is expected that the assigned strains applied to the model boundaries will be transferred without distortions into the internal cells of the model.

Upon completion of the geometry testing computations, the following conditions have been checked:

- the model exclusive of the containing environment is free of tension stresses;

- the values of the computed strains in the model also remain within the preset limits;

- there is no rotation of horizontal stress vectors, i.e. the computed directions should match the preset 
direction, in this case the minimum stress has a direction of $140-320^{\circ}$ and maximum horizontal stress is $50-230^{\circ}$.

The results of the grid geometry test have shown the absence of impact of the grid in use on the occurring stresses. The obtained strain values by area and by computed cube are the same as the preset ones, while tensions stresses are absent in the model. The minimum horizontal stress direction is preserved within the model according to the results of the numerical computations according to the boundary conditions.

\section{Filling the grid with mechanical properties}

Mechanical properties of the rock can be propagated, like any other petrophysical parameters of the environment, using geostatistics methods by the geological model data and well logging data, or directly computed from the results of the seismic exploration data inversion. Propagation can be applied directly to elasticity and strength parameters, or indirectly to the petrophysical parameters from which the elasticity and strength parameters are computed. Since the modeling region has a limited number of wells with complete sets of original GIS data for computation of geomechanical properties, it is the initial data (DTP, DTS, RHOB, GR) that have been defined as the basic data for propagation in the interwell space.

Propagation of properties in the interwell space requires using seismic data to account for lateral changes in the environment. For this purpose, seismic cubes were used; particularly, the area of study was covered by an amplitude cube in the depth domain, interval velocity cube in the depth domain, $P$-, $S$-impedance cubes and $V_{p} / V_{s}$ ratio cube in the time domain. The substrate for propagation of properties was the interval velocity cube in the depth domain and $P$-impedance cube transferred from the time domain to the depth domain using depth/time paired surfaces.

Therefore, modeling of mechanical properties in the interwell space required solving the following tasks:

- quality of GIS information was assessed for data scaling into the structural grid (performed in scope of the 1D modeling);

- a velocity model was built and seismic inversion data were transferred to the depth domain;

- scaling of the seismic inversion data into the structural grid was performed;

- modeling was performed for density, gamma-ray logging, and interval transit time of the longitudinal and transverse waves in the interwell space using geostatistics methods;

- cubes of elasticity and strength parameters were computed on the basis of dependencies defined at the stage of the unidimensional geomechanical modeling.

\section{Stress computation using the finite element method}

Unlike mechanical properties of the rock, stresses characterize the entire geological environment as a complete system. In such a system, behavior of its single element is not solely determined by its own properties but also depends on the entire containing environment and loads it is exposed to. Therefore, stresses cannot be computed using geostatistics methods; their modeling requires use of other mathematical algorithms. In this project, stress state is computed using the finite element method [23-30]. The 3D geomechanical model is built using cubes of elasticity and strength properties: Young's modulus, Poisson's ratio, internal friction angle, uniaxial compression and tension strength calculated using the correlations derived from density cubes, transit velocities of the longitudinal and transverse waves, obtained by geostatistics methods from the well data.

As a result of the computation using the finite element method, each cell was assigned with all the components of the stress tensor affecting it. An example of the computed direction of the minimum horizontal pressure for one of the cell layers within the Ordovic and Cambrian strata is shown in Fig. 2. The direction of stresses is maintained throughout the entire area and constitutes $\sim 140^{\circ}$ for the minimum horizontal stress. Rotation of stresses is confined to the near-fault part.
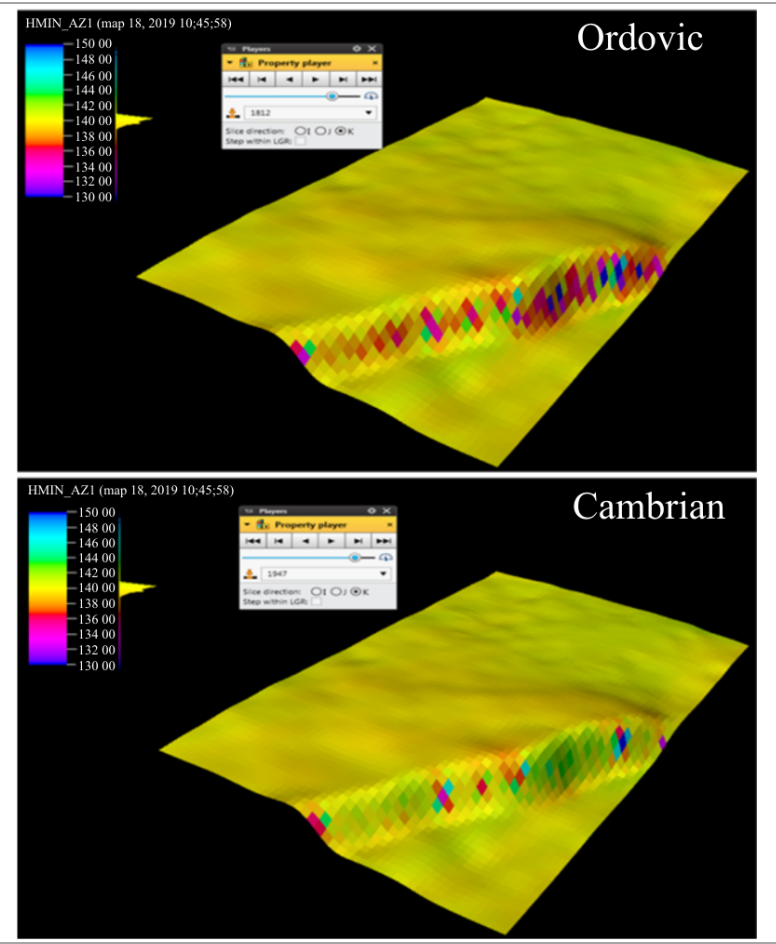

Fig. 2. Orientation of minimum horizontal stress 


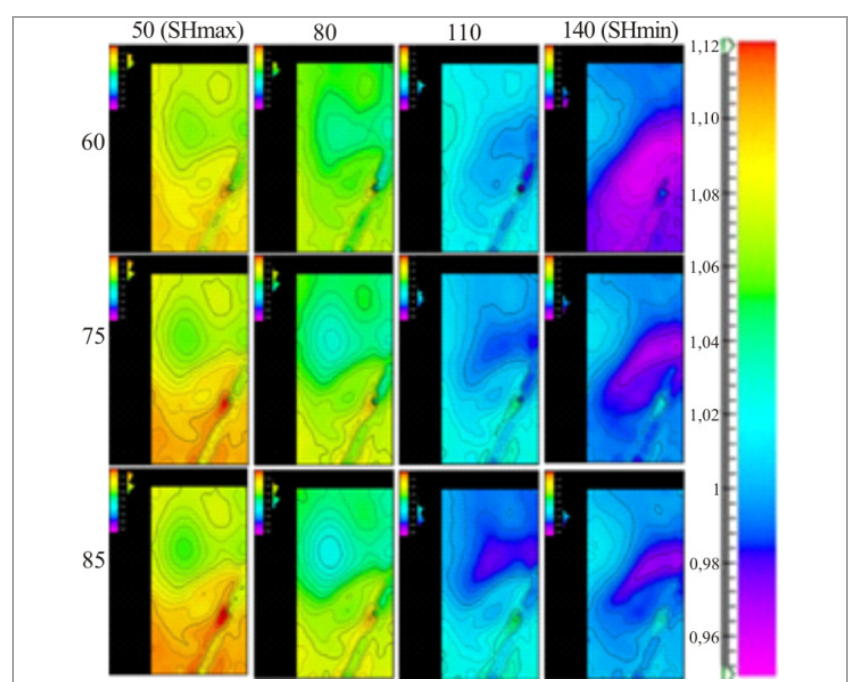

Fig. 3. Distribution of mean caving gradient values in the Ordovic interval depending on the drilling angle and azimuth

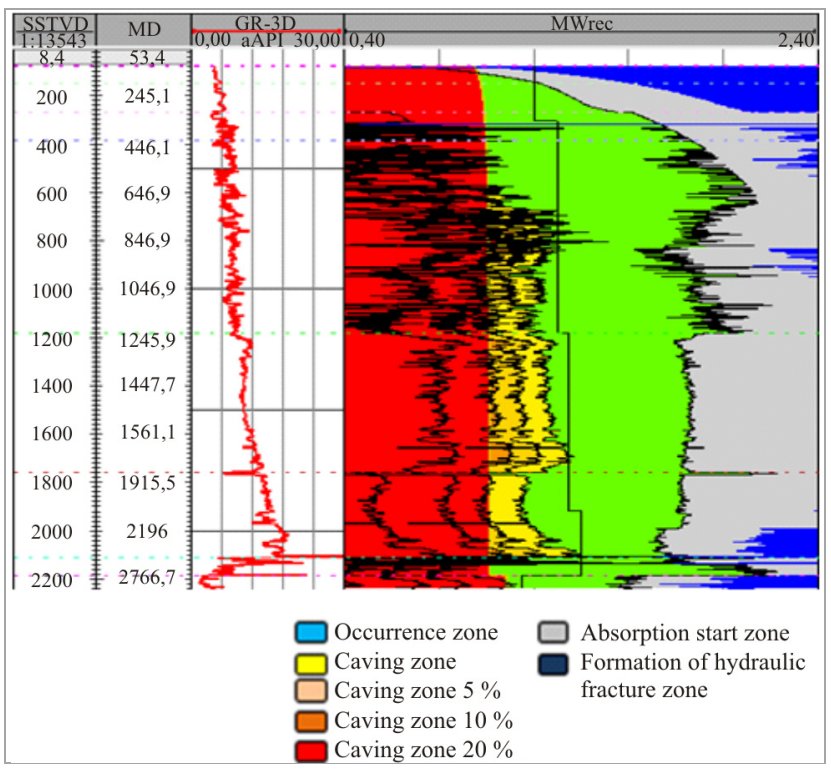

Fig. 4. Computation of well walls stability

\section{Use of Geomechanical Modeling Results}

Based on the obtained 3D model (mechanical properties, cube of reservoir pressures, and the results of computation of the environment's stress state), computation has been performed for the cubes of absorptions gradient, hydraulic fracturing gradient and caving gradient for various azimuths and drilling angles for each layer of the model. Fig. 3 shows a distribution of mean caving gradient values in the Ordovic interval depending on the drilling angle and azimuth. Further, based on the geomechanical modeling, the trajectory and structure of the wells were optimized, and the wellbore stability computation was performed for the project production wells. Fig. 4 shows an example of such a computation for one of the wells in the field under study. Recommendations have been developed concerning the drilling mud composition and parameters, which, in turn, has a decisive impact on the accident-free construction of wells [31-38]. In further researches, the geomechanical model can be used to solve the tasks of an effective field development, including planning of formation hydraulic fracturing [39-46].

\section{Conclusion}

The methods considered in this study enabled development of a numerical three-dimensional geomechanical model of one of the fields in the Baltic Sea shelf. On the basis of the 3D model, design solutions for construction of production wells were implemented. Stability computation was performed for the planned territories. Gradients of pore pressure, caving pressure, absorption pressure and hydraulic fracturing pressure were determined. A safe window of the drilling mud density was established for all the wells. Trajectory and structure of wells were corrected to ensure safe drilling and finishing conditions. Requirements to the drilling mud parameters were developed to ensure wellbore stability. The aforementioned results have been achieved by using the principles of geomechanical modeling.

\section{References}

1. Fischer K., Henk A. Generating and Calibrating 3D Geomechanical Reservoir Models. 75th EAGE conference \& exhibition incorporating SPE EUROPEC, 2013, no. 75, 348 p.

2. Byoung Yoon Park, Sobolik R. Steven, Courtney G. Herrick Geomechanical Model Calibration Using Field Measurements for a Petroleum Reserve. Rock Mechanics and Rock Engineering, 2018, no. 3, pp. 925-943.

3. Henk A., Fischer K., Winter I. Prediction of tectonic stresses and fracture networks with geomechanical reservoir models. Berichte - Deutsche Wissenschaftliche Gesellschaft für Erdöl, Erdgas und Kohle e.V. Forschungsbericht, 2014, no. 725, $205 \mathrm{p}$.

4. Pavlov V., Korel'skii E., Butula K., Kliubin A., Maksimov D., Zinov'ev A., Zadvornov D., Grachev O. Sozdanie 4D-geomekhanicheskoi modeli dlia opredeleniia vliianiia razrabotki mestorozhdeniia na geometriiu treshchin GRP [Creation of a 4D geomechanical model to determine the effect of field development on the fracture geometry]. SPE 1822020-RU, 2016.

5. Ganaeva M.R., Sukhodanova S.S., Khaliulin R.R., Khaliulin R.R. Postroenie trekhmernoi geomekhanicheskoi modeli mestorozhdeniia na Sakhalinskom 
shel'fe s tsel'iu planirovaniia mnogostadiinogo gidrorazryva plasta [Sakhalin offshore oilfield hydraulic fracturing optimization by building a 3D geomechanical model]. Neftianoe khoziaistvo, 2018, no. 6, pp. 108-111.

6. Kashnikov Iu.A., Shustov D.V., Iakimov S.Iu., Ashikhmin S.G., Voevodkin V.L. Razrabotka geologo-geomekhanicheskoi modeli turneifamenskogo ob"ekta Gagarinskogo mestorozhdeniia [Creating of geological geomechanical model of TournaisianFamennian object of Gagarinskoye oil field]. Neftianoe khoziaistvo, 2013, no. 2, pp. 50-54.

7. Predein A.A., Klykov P.I. Postroenie geomekhanicheskoi modeli $i$ raschet ustoichivosti stvola skvazhiny na primere odnogo iz mestorozhdenii Permskogo kraia [Geomechanical model and borehole stability prediction for one of the fields of perm region]. Burenie i neft', 2016, no. 4.

8. Albukhari T.M., Beshish G.K., Abouzbeda M.M., Madi A. Geomechanical wellbore stability analysis for the reservoir section in J-NC186 oil field. Tunisian Society for Rock Mechanics, 2018, pp. 179-193.

9. Ashikhmin S.G., Kukhtinskii A.E. Modelirovanie napriazhenno-deformirovannogo sostoianiia neobsazhennoi skvazhiny [Simulation of stressdeformed state of open well]. Vestnik Permskogo natsional'nogo issledovatel'skogo politekhnicheskogo universiteta. Geologiia. Neftegazovoe i gornoe delo, 2014, no. 11, pp. 99-104.

10. Garshina O.V., Predein A.A., Klykov P.I., Khvoshchin P.A., Nekrasova I.L. Geomekhanicheskoe modelirovanie kak neot"emlemaia chast' kompleksnogo podkhoda $\mathrm{k}$ stroitel'stvu skvazhin $\mathrm{v}$ slozhnykh gorno-geologicheskikh usloviiakh [Geomechanical modeling as an integral part of an integrated approach to well construction in difficult mining and geological conditions]. Neftepromyslovoe delo, 2017, no. 5, pp. 28-33.

11. Lukin S.V., Esipov S.V., Zhukov V.V, Ovcharenko Iu.V., Khomutov A.Iu., Shevchuk T.N., Susliakov I.V. Raschet ustoichivosti stvola skvazhiny dlia predotvrashcheniia oslozhnenii $\mathrm{v}$ burenii [Borehole stability prediction to avoid drilling failures]. Neftianoe khoziaistvo, 2016, no. 6, pp. 70-73.

12. Pavlov V.A., Lushev M.A., Korel'skii E.P., Laskin P.G. Razvitie geomekhanicheskogo modelirovaniia $\mathrm{v}$ Rossii [The development of geomechanical modeling in Russia]. Tekhnologii nefti $i$ gaza, 2017, no. 6, pp. 3-9.

13. Davletova A.R., Kireev V.V., Knutova S.R., Pestrikov A.V., Fedorov A.I. Razrabotka korporativnogo geomekhanicheskogo simuliatora dlia modelirovaniia ustoichivosti stvola skvazhiny [Development of corporate geomechanics simulator for wellbore stability modeling]. Neftianoe khoziaistvo, 2018, no. 6, pp. 88-92.
14. Mitiaev M.Iu., Belozerov B.V., Lukin S.V. Raschet napravlenii osei maksimal'nykh napriazhenii po dannym gidrorazryva plasta [Calculation of the directions of the axes of maximum stresses according to hydraulic fracturing]. Neftianoe khoziaistvo, 2015, no. 8, pp. $70-71$.

15. Zoback M. Reservoir geomechanics. Cambridge University Press, 2007, $505 \mathrm{p}$.

16. Fjaer E., Holt R.M., Horsrud P., Raaen A.M., Risness R. Petroleum related rock mechanics. Developments in Petroleum Science, 33, $346 \mathrm{p}$.

17. Hoek E., Brown E.T. Underground excavations in rock. London: Institution of Mining and Metallurgy, $1980,527 \mathrm{p}$.

18. Kashnikov Iu.A., Ashikhmin S.G. Mekhanika gornykh porod pri razrabotke mestorozhdenii uglevodorodnogo syr'ia [Rock mechanics in the development of hydrocarbon deposits]. Moscow: Nedra, 2007, 467 p.

19. Hamid O. et al. Reservoir geomechanics in carbonates. SPE Middle East Oil \& Gas Show and Conference. Society of Petroleum Engineers. Manama, 2017. DOI: https://doi.org/10.2118/183704-MSpdf

20. Hongcai Wang, Wei-Hua Zhao, Dongsheng Sun, Binbin Guo. Mohr-Coulomb yield criterion in rock plastic mechanics. Acta Geophysica Sinica, 2012, no. 12 , pp. 4231-4238.

21. Al-Ajml A.M. Zimmerman R.W. Stability Analysis of Vertical Boreholes Using the MogiCoulomb Failure Criterion. Int. J. Rock Mechanics \& Mining Science, 2006, vol. 43, pp. 1200-1211.

22. Ewy R.T. Wellbore stability predictions by use of a modified Lade criterion. SPE 56862-PA, 1999, pp. 85-91.

23. Gladyshev S.V., Popov S.N., Shustov D.V. Prognoz napriazhenno-deformirovannogo sostoianiia gornogo massiva metodom konechnykh elementov pri razrabotke Shershnevskogo mestorozhdeniia nefti na osnove trekhmernoi geologicheskoi modeli [Forecast of the stress-strain state of the rock mass using the finite element method in the development of the Shershnevsky oil field based on a three-dimensional geological model]. Vestnik Permskogo natsional'nogo issledovatel'skogo politekhnicheskogo universiteta. Geologiia. Neftegazovoe i gornoe delo, 2008, no. 3, pp. 44-54.

24. Shustov D.V., Ermashov A.O. Prognoz sdvizhenii i deformatsii gornogo massiva Tishinskogo mestorozhdeniia metodami konechnykh i diskretnykh elementov [Forecast of displacement and deformations of rock mass at tishinskiy deposit by final and discreteselements]. Vestnik Permskogo natsional'nogo issledovatel'skogo politekhnicheskogo universiteta. Geologiia. Neftegazovoe i gornoe delo, 2012, no. 5, pp. 89-96.

25. Sashurin A.D., Balek A.E. Sovershenstvovanie metodiki naturnykh zamerov napriazhenno- 
deformirovannogo sostoianiia bol'shikh uchastkov gornogo massiva [Improvement of field measurement of stress-deformed state of the large massif parts]. Vestnik Permskogo natsional'nogo issledovatel'skogo politekhnicheskogo universiteta. Geologiia. Neftegazovoe $i$ gornoe delo, 2014, no. 11, pp. 105-120.

26. Asanov V.A., Toksarov V.N., Samodelkina N.A., Bel'tiukov N.L., Udartsev A.A. Otsenka napriazhennodeformirovannogo sostoianiia netronutogo massiva na mestorozhdenii Zhaman-Aibat [Evaluation of stresseddeformed state of virgin rock at zhaman-aibat deposit]. Vestnik Permskogo natsional'nogo issledovatel'skogo politekhnicheskogo universiteta. Geologiia. Neftegazovoe i gornoe delo, 2014, no. 12, pp. 56-66. DOI: $10.15593 / 2224-9923 / 2014.12 .7$

27. Nekrasov S.V., Andreiko S.S. Vychislitel'naia skhema otsenki napriazhenno-deformirovannogo sostoianiia kusochnoodnorodnoi trekhmernoi uprugoi sredy na osnove nepriamogo metoda granichnykh elementov [Computational scheme of evaluating strain-stress state of piecewisehomogeneous three-dimensional elastic environment based on indirect method of boundary elements]. Vestnik Permskogo natsional'nogo issledovatel'skogo politekhnicheskogo universiteta. Geologiia. Neftegazovoe $i$ gornoe delo, 2015, no. 16, pp. 86-97. DOI: $10.15593 / 2224-9923 / 2015.16 .10$

28. Zhou Bo, Sun Bo, Xue Shifeng Extended finite element method for fracture mechanics of rock. Journal of China University of Petroleum, Edition of Natural Science, 2016, no. 4, pp. 121-126.

29. Ke Xu, Junsheng Dai, Xiaolong Fu, Qiqiang Ren, Congning Liu, Yun Zhao. Discussion on the fracture of layered rock mass based on the finite element method. Journal of Geomechanics, 2015, no. 3, pp. 330-340.

30. Pryhorovska T.O., Chaplinskiy S.S., Kudriavtsev I.O. Finite element modelling of rock mass cutting by cutters for PDC drill bits. Petroleum Exploration and Development, 2015, no. 6, pp. 812-816.

31. Seredin V.V., Parshina T.Iu. Izmenenie mass sviazannoi vody $\mathrm{v}$ glinakh pri szhatii [Mass change of bound water in clays under compression]. Vestnik Permskogo natsional'nogo issledovatel'skogo politekhnicheskogo universiteta. Geologiia. Neftegazovoe i gornoe delo, 2017, vol. 16, no. 1, pp. 23-32. DOI: 10.15593/2224-9923/2017.1.3

32. Nekrasova I.L., Kazymov K.P., Predein A.A., Khvoshchin P.A., Klykov P.I., Garshina O.V., Osovetskii B.M., Moloshtanova N.E., Zhdanov V.M. Izmenenie sostava i struktury terrigennykh porod pod vozdeistviem burovykh rastvorov [Change of the composition and texture of terrigenious rocks under the influence of drilling fluids]. Geologiia, geofizika $i$ razrabotka neftianykh i gazovykh mestorozhdenii, 2017, no. 6, pp. 37-43.

33. Khubbatov A.A., Gaidarov A.M., Norov A.D., Gaidarov M.M-R. Ingibiruiushchie burovye rastvory $\mathrm{i}$ ustoichivost' glinistykh porod [The inhibiting drilling muds and stability of clay rocks]. Neftianoe khoziaistvo, 2015, no. 5, pp. 64-67.

34. Goronovich S.N., Kozhina T.V., Oleinikov A.N., Bel'skii D.G. Priroda suzheniia stvola skvazhin pri vskrytii solei bol'shoi tolshchiny [The nature of the restriction borehole at the opening of thick salt]. Neftianoe khoziaistvo, 2014, no. 1, pp. 41-43.

35. Nikolaev N.I., Leusheva E.L. Povyshenie effektivnosti bureniia tverdykh gornykh porod [Increasing of hard rocks drilling efficiency]. Neftianoe khoziaistvo, 2016, no. 3, pp. 68-71.

36. Bin Wu, Jian Wang, Fuchang Shu, Xingjin Xiang, Mingshun Nie. Study and application of oil-based drilling fluids for horizontal drilling. Journal of Oil and Gas Technology, 2014, no. 2, pp. 101-104.

37. Caenn Ryen The history of drilling fluids, classified by date ranges. Oil-Industry History, 2018, no. 1, pp. $160-161$.

38. Yicheng Wu, Li Zhao, Jiashui Yu, Jing Li, Xuebin Liu, Xin Chen, Hengzhu Hu. Horizontal well drilling fluid technologies in Well MBHW610 of Mobei Field. Journal of Oil and Gas Technology, 2014, no. 6, pp. 100-103.

39. Pen'kov G.M., Karmanskii G.M., Petrakov D.G. Issledovanie zavisimostei mezhdu fiziko-mekhanicheskimi svoistvami peschanika i skorost'iu prokhozhdeniia uprugikh voln [Study of the relationships between physical and mechanical properties of the sandstone and velocity of elastic waves]. Vestnik Permskogo natsional'nogo issledovatel'skogo politekhnicheskogo universiteta. Geologiia. Neftegazovoe i gornoe delo, 2020, vol. 20, no. 1, pp. 27-36. DOI: 10.15593/2224-9923/2020.1.3

40. Kashnikov Iu.A., Ashikhmin S.G., Shustov D.V., Chernyshov S.E. Otsenka ustoichivosti stenok skvazhin $\mathrm{v}$ usloviiakh otsutstviia dostovernoi informatsii o geomekhanicheskikh kharakteristikakh porod [Evaluation of borehole stability with lack of reliable information about geomechanical characteristics of rocks]. Neftianoe khoziaistvo, 2015, no. 1, pp. 41-43.

41. Ibragimov A.N., Salimov V.G., Ibatullin R.R., Nasybullin A.V., Salimov O.V. Geomekhanicheskie usloviia effektivnogo primeneniia kislotnogo gidrorazryva plastov [Geomechanical conditions of successful acid fracturing applications]. Neftianoe khoziaistvo, 2014, no. 7, pp. 32-36.

42. Kashnikov Iu.A., Ashikhmin S.G., Smetannikov O.Iu., Shustov D.V. Geomekhanicheskii analiz uslovii razvitiia treshchiny povtornogo gidrorazryva 
plasta [Geomechanics research of oriented refracturing development conditions]. Neftianoe khoziaistvo, 2014, no. 6 , pp. 44-47.

43. Kashnikov Iu.A., Ashikhmin S.G., Cherepanov S.S., Baldina T.R., Filippov E.V. Opyt sozdaniia orientirovannoi treshchiny gidrorazryva plasta na mestorozhdeniiakh OOO "LUKOIL-PERM" [The experience of creating an oriented hydraulic fracture in the fields of LLC "LUKOIL-PERM"]. Neftianoe khoziaistvo, 2014, no. 6, pp. 40-43.

44. Cambou Bernard, Darve Félix, Nicot François Particle methods in geomechanics. International Journal for Numerical and Analytical Methods in Geomechanics, 2019, no. 5, pp. 831-832.

45. Domonik A., Lukaszewski P., Bobrowska A., Wilczyński P. The Role of Geomechanics in Unconventional Shale Gas Reservoir Performance. Goldschmidt Conference, 2016, no. 26, 695 p.

46. Spokas K., Peters C.A., Pyrak-Nolte L.J. Modeling geomechanical deformation in reactive fractures Performance. Goldschmidt Conference, 2016, no. 26, 2934 p.

\section{Библиографический список}

1. Fischer K., Henk A. Generating and Calibrating 3D Geomechanical Reservoir Models // 75th EAGE conference \& exhibition incorporating SPE EUROPEC 2013. - 2013. - № 75. - P. 348.

2. Byoung Yoon Park, Sobolik R. Steven, Courtney G. Herrick geomechanical model calibration using field measurements for a petroleum reserve // Rock Mechanics and Rock Engineering. - 2018. - № 3. P. 925-943.

3. Henk A., Fischer K., Winter I. Prediction of tectonic stresses and fracture networks with geomechanical reservoir models // Berichte - Deutsche Wissenschaftliche Gesellschaft für Erdöl, Erdgas und Kohle e.V. Forschungsbericht. - 2014. - № 725. P. 205.

4. Создание 4D-геомеханической модели для определения влияния разработки месторождения на геометрию трещин ГРП / В. Павлов, Е. Корельский, К. Бутула, А. Клюбин, Д. Максимов, А. Зиновьев, Д. Задворнов, О. Грачев // SPE 1822020-RU. - 2016.

5. Построение трехмерной геомеханической модели месторождения на Сахалинском шельфе с целью планирования многостадийного гидроразрыва пласта / М.Р. Ганаева, С.С. Суходанова, Р.Р. Халиулин, Р.Р. Халиулин // Нефтяное хозяйство. - 2018. - № 6. - С. 108-111.

6. Разработка геолого-геомеханической модели турней-фаменского объекта Гагаринского месторождения / Ю.А. Кашников, Д.В. Шустов, С.Ю. Якимов, С.Г. Ашихмин, В.Л. Воеводкин // Нефтяное хозяйство. - 2013. - № 2. - С. 50-54.
7. Предеин А.А., Клыков П.И. Построение геомеханической модели и расчет устойчивости ствола скважины на примере одного из месторождений Пермского края // Бурение и нефть. - 2016. - № 4.

8. Geomechanical wellbore stability analysis for the reservoir section in J-NC186 oil field / T.M. Albukhari, G.K. Beshish, M.M. Abouzbeda, A.Madi // Tunisian Society for Rock Mechanics. - 2018. - P. 179-193.

9. Ашихмин С.Г., Кухтинский А.Э. Моделирование напряженно-деформированного состояния необсаженной скважины // Вестник Пермского национального исследовательского политехнического университета. Геология. Нефтегазовое и горное дело. - 2014. - № 11. - С. 99-104.

10. Геомеханическое моделирование как неотъемлемая часть комплексного подхода к строительству скважин в сложных горно-геологических условиях / О.В. Гаршина, А.А. Предеин, П.И. Клыков, П.А. Хвощин, И.Л. Некрасова // Нефтепромысловое дело. - 2017. - № 5. - С. 28-33.

11. Расчет устойчивости ствола скважины для предотвращения осложнений в бурении / С.В. Лукин, С.В. Есипов, В.В. Жуков, Ю.В. Овчаренко, А.Ю. Хомутов, Т.Н. Шевчук, И.В. Сусляков // Нефтяное хозяйство. - 2016. - № 6. - С. 70-73.

12. Развитие геомеханического моделирования в России / В.А. Павлов, М.А. Лушев, Е.П. Корельский, П.Г. Ласкин // Технологии нефти и газа. 2017. - № 6. - С. 3-9.

13. Разработка корпоративного геомеханического симулятора для моделирования устойчивости ствола скважины / А.Р. Давлетова, В.В. Киреев, С.Р. Кнутова, А.В. Пестриков, А.И. Федоров // Нефтяное хозяйство. - 2018. - № 6. - С. 88-92.

14. Митяев М.Ю., Белозеров Б.В., Лукин С.В. Расчет направлений осей максимальных напряжений по данным гидроразрыва пласта // Нефтяное хозяйство. -2015 . - № 8. - С. 70-71.

15. Zoback M. Reservoir geomechanics. Cambridge University Press, 2007. -505 p.

16. Petroleum related rock mechanics / E. Fjaer, R.M. Holt, P. Horsrud, A.M. Raaen, R. Risness // Developments in Petroleum Science. - Vol. 33. - 346 p.

17. Hoek E., Brown E.T. Underground excavations in rock. - London: Institution of Mining and Metallurgy, 1980. $-527 \mathrm{p}$.

18. Кашников Ю.А., Ашихмин С.Г. Механика горных пород при разработке месторождений углеводородного сырья. - М.: Недра, 2007. - 467 с.

19. Reservoir geomechanics in carbonates / O. Hamid [et al.] // SPE Middle East Oil \& Gas Show and Conference / Society of Petroleum Engineers. Manama, 2017.

20. Coulomb yield criterion in rock plastic mechanics / Wang Hongcai, Zhao Weihua, Sun Dong- 
sheng, Guo Binbin Mohr // Acta Geophysica Sinica. 2012. - № 12. - P. 4231-4238.

21. Al-Ajml A.M. Zimmerman R.W. Stability analysis of vertical boreholes using the mogicoulomb failure criterion // Int. J. Rock Mechanics \& Mining Science. - 2006. - Vol. 43. - P. 1200-1211.

22. Ewy R.T. Wellbore stability predictions by use of a modified Lade criterion // SPE 56862-PA. 1999. - P. 85-91.

23. Гладышев С.В., Попов С.Н., Шустов Д.В. Прогноз напряженно-деформированного состояния горного массива методом конечных элементов при разработке Шершневского месторождения нефти на основе трехмерной геологической модели // Вестник Пермского национального исследовательского политехнического университета. Геология. Нефтегазовое и горное дело. - 2008. - № 3. - С. 44-54.

24. Шустов Д.В., Ермашов А.О. Прогноз сдвижений и деформаций горного массива Тишинского месторождения методами конечных и дискретных элементов // Вестник Пермского национального исследовательского политехнического университета. Геология. Нефтегазовое и горное дело. - 2012. - № 5. - С. 89-96.

25. Сашурин А.Д., Балек А.Е. Совершенствование методики натурных замеров напряженнодеформированного состояния больших участков горного массива // Вестник Пермского национального исследовательского политехнического университета. Геология. Нефтегазовое и горное дело. 2014. - № 11. - C. 105-120.

26. Оценка напряженно-деформированного состояния нетронутого массива на месторождении Жаман-Айбат / В.А. Асанов, В.Н. Токсаров, Н.А. Самоделкина, Н.Л. Бельтюков, А.А. Ударцев // Вестник Пермского национального исследовательского политехнического университета. Геология. Нефтегазовое и горное дело. - 2014. - № 12. C. 56-66. DOI: 10.15593/2224-9923/2014.12.7

27. Некрасов С.В., Андрейко С.С. Вычислительная схема оценки напряженно-деформированного состояния кусочно-однородной трехмерной упругой среды на основе непрямого метода граничных элементов // Вестник Пермского национального исследовательского политехнического университета. Геология. Нефтегазовое и горное дело. - 2015. - № 16. C. 86-97. DOI: 10.15593/2224-9923/2015.16.10

28. Zhou Bo, Sun Bo, Xue Shifeng extended finite element method for fracture mechanics of rock // Journal of China University of Petroleum, Edition of Natural Science. - 2016. - № 4. - P. 121-126.

29. Discussion on the fracture of layered rock mass based on the finite element method / Xu Ke, Dai Junsheng, $\mathrm{Fu}$ Xiaolong, Ren Qiqiang, Liu Congning, Zhao Yun // Journal of Geomechanics. 2015. - № 3. - P. 330-340.
30. Pryhorovska T.O., Chaplinskiy S.S., Kudriavtsev I.O. Finite element modelling of rock mass cutting by cutters for PDC drill bits // Petroleum Exploration and Development. - 2015. - № 6. P. 812-816.

31. Середин В.В., Паршина Т.Ю. Изменение масс связанной воды в глинах при сжатии // Вестник Пермского национального исследовательского политехнического университета. Геология. Нефтегазовое и горное дело. - 2017. - Т.16, №1. - С. 23-32. DOI: $10.15593 / 2224-9923 / 2017.1 .3$

32. Изменение состава и структуры терригенных пород под воздействием буровых растворов / И.Л. Некрасова, К.П. Казымов, А.А. Предеин, П.А. Хвощин, П.И. Клыков, О.В. Гаршина, Б.М. Осовецкий, Н.Е. Молоштанова, В.М. Жданов // Геология, геофизика и разработка нефтяных и газовых месторождений. - 2017. - № 6. - С. 37-43.

33. Хуббатов А.А., Гайдаров А.М., Норов А.Д., Гайдаров М.М-Р Ингибирующие буровые растворы и устойчивость глинистых пород // Нефтяное хозяйство. -2015 . - № 5. - С. 64-67.

34. Природа сужения ствола скважин при вскрытии солей большой толщины / С.Н. Горонович, Т.В. Кожина, А.Н. Олейников, Д.Г. Бельский // Нефтяное хозяйство. - 2014. - № 1. - С. 41-43.

35. Николаев Н.И., Леушева Е.Л. Повышение эффективности бурения твердых горных пород // Нефтяное хозяйство. - 2016. - № 3. C. $68-71$.

36. Study and application of oil-based drilling fluids for horizontal drilling / Wu Bin, Wang Jian, Shu Fuchang, Xiang Xingjin, Nie Mingshun // Journal of Oil and Gas Technology. - 2014. - № 2. P. 101-104.

37. Caenn Ryen The history of drilling fluids, classified by date ranges // Oil-Industry History. 2018. - № 1. - P. 160-161.

38. Horizontal well drilling fluid technologies in Well MBHW610 of Mobei Field / Wu Yicheng, Zhao $\mathrm{Li}, \mathrm{Yu}$ Jiashui, Li Jing, Liu Xuebin, Chen Xin, Hu Hengzhu // Journal of Oil and Gas Technology. 2014. - № 6. - P. 100-103.

39. Пеньков Г.М., Карманский Г.М., Петраков Д.Г. Исследование зависимостей между физико-механическими свойствами песчаника и скоростью прохождения упругих волн // Вестник Пермского национального исследовательского политехнического университета. Геология. Нефтегазовое и горное дело. - 2020. - Т. 20, № 1. C. 27-36. DOI: 10.15593/2224-9923/2020.1.3

40. Оценка устойчивости стенок скважин в условиях отсутствия достоверной информации о геомеханических характеристиках пород / Ю.А. Кашников, С.Г. Ашихмин, Д.В. Шустов, 
С.Е. Чернышов // Нефтяное хозяйство. - 2015. № 1. - C. 41-43.

41. Геомеханические условия эффективного применения кислотного гидроразрыва пластов / А.Н. Ибрагимов, В.Г. Салимов, Р.Р. Ибатуллин, А.В. Насыбуллин, О.В. Салимов // Нефтяное хозяйство. - 2014. - № 7. - С. 32-36.

42. Геомеханический анализ условий развития трещины повторного гидроразрыва пласта / Ю.А. Кашников, С.Г. Ашихмин, О.Ю. Сметанников, Д.В. Шустов // Нефтяное хозяйство. - 2014. - № 6. C. $44-47$.

43. Опыт создания ориентированной трещины гидроразрыва пласта на месторождениях ООО «ЛУКОЙЛ-ПЕРМЬ» / Ю.А. Кашников, С.Г. Аших- мин, С.С. Черепанов, Т.Р. Балдина, Е.В. Филиппов // Нефтяное хозяйство. - 2014. - № 6. -С. 40-43.

44. Cambou Bernard, Darve Félix, Nicot François Particle methods in geomechanics // International Journal for Numerical and Analytical Methods in Geomechanics. - 2019. - № 5. - P. 831-832.

45. The Role of Geomechanics in Unconventional Shale Gas Reservoir Performance / A. Domonik, P. Lukaszewski, A. Bobrowska, P. Wilczyński // Goldschmidt Conference. - 2016. - № 26 . P. 695.

46. Spokas K., Peters C.A., Pyrak-Nolte L.J. Modeling geomechanical deformation in reactive fractures Performance // Goldschmidt Conference. 2016. - № 26. - P. 2934.

Please cite this article in English as:

Liadova N.A., Klykov P.I., Predein A.A. Numerical solution of geomechanics problems (the case of the Baltic sea offshore field). Perm Journal of Petroleum and Mining Engineering, 2020, vol.20, no.2, pp.126-136. DOI: 10.15593/2224-9923/2020.2.3

Просьба ссылаться на эту статью в русскоязычных источниках следующим образом:

Лядова Н.А., Клыков П.И., Предеин А.А. Численное решение задач геомеханики (на примере месторождения шельфа Балтийского моря) // Вестник Пермского национального исследовательского политехнического университета. Геология. Нефтегазовое и горное дело. - 2020. - Т.20, №2. - C.126-136. DOI: 10.15593/2224-9923/2020.2.3 